\title{
Maruka Pod Borer [Maruca vitrata (Geyer)] Management in Blackgram (Vigna mungo L.) in Krishna District of Andhra Pradesh, India
}

\author{
P. Sudha Jacob ${ }^{1^{*}}$ and Revathi ${ }^{2}$
}

${ }^{1}$ Krishi Vigyan Kendra, Ghantasala, Andhra Pradesh, India

${ }^{2} S$ V Agricultural College, Tirupati, Andhra Pradesh, India

*Corresponding author

\section{A B S T R A C T}

On farm trials in ten locations were conducted to evaluate efficacy of IPM strategies against maruka pod borer [Maruca vitrata (Geyer)] with emphasis on timely observation of the pest incidence, levels of infestation and alternation of different groups of

\section{Keywords}

Blackgram, Pod borer, IPM, Yield and net income

Article Info

Accepted:

17 June 2019

Available Online:

10 July 2019 insecticides properly so that even with repeated use of insecticides having different mode of action with an aim to see that the pest may not develop resistance against particular group of insecticides besides achieving proper management of the maruka pod borer and to create awareness among the farming community during rabi, 2014-15 to 2017-18 in the farmer's fields in Krishna District of Andhra Pradesh. By adoption of IPM practices in all the four years, the pod borer damage was reduced on an average by 9.48 per cent compared to 17.08 per cent in farmers practice. This has resulted in reduction in the average cost of cultivation by Rs. 3099.00 per hectare and the average net income was improved by Rs. 10417 per hectare compared to the farmers practice. The average yield levels in the demonstration (13.33 qt/ha) improved by 8.67 per cent compared to farmers practice (12.36 qt/ha) and giving a clear message that adoption of IPM practices with emphasis observation of the pest intensity and using different insecticides helped in reducing the pest levels, damage and improving yield; helps in improving the decision making capacity and net income levels to the resource poor farmers.

\section{Introduction}

Blackgram (Vigna mungo L.) is the fourth most important short-duration pulse crop grown in India, contributing $10 \%$ of national pulses production. It is native to Indian subcontinent and belongs to the family leguminosae; sub family Papilionaceae. In coastal areas of Andhra Pradesh, after Kharif rice crop, blackgram is cultivated as relay crop under low input management without use of any additional inputs utilizing only the residual moisture and nutrients. The seeds are sown in the standing rice crop 3-4 days before harvesting and continued after harvesting of rice crop. Photo-insensitive high yielding varieties suitable for rice fallow conditions were developed so that the rabi rice fallow blackgram cultivation is profitable and helps in promoting sustainable cereal-pulse based cropping system enriching even the soil fertility. In Andhra Pradesh it is cultivated in 
12.5 lakh acres with a production of 3.29 lakh tonnes and with a productivity of $263 \mathrm{~kg} / \mathrm{acre}$ (Vyavasaya Panchagam, 2018).

On an average, 2.5 to 3.0 million tonnes of pulses are lost annually due to pest problems (Rabindra et al., 2004) with a monetary value of nearly 6,000 crores due to ravages of insect pest complex (Reddy, 2009). A large number of insects have been recorded feeding on blackgram from sowing till harvesting. Lal (1985) reported 64 species of insects that attack mungbean in field.

The yield loss on urdbean due to insect pests at various stages of the crop growth accounts 30 to 54.3 per cent in India (Nayar et al., 1976; Singh and Allen 1980; Dhuri and Singh 1983; Saxena, 1983; Pandey et al., 1991; Justin et al., 2015). Among the insect pests spotted pod borer, Maruca vitrata (G.) is the devastating pest of pulses (Lal and Sachan 1987; Shivaraju et al., 2011). It infests mungbean, urdbean, pigeonpea, cowpea and field bean in southern zone of A.P (Sharma et al., 2000). The spotted pod borer became serious pest of grain legumes in the tropics and subtropics due its extensive host range, distribution and destructiveness. Due to availability of several hosts throughout the year in different seasons / situations, it became a persistent pest in pulses. Due to its destructiveness at critical stages of crop growth viz., flowering and pod development stages especially to the economic plant parts such as flower buds, flowers and pods, it became a significant constraint to attain the maximum productivity from grain legumes.

Spotted pod borer M. vitrata larvae feeds on anthers, filaments, styles, stigma and ovaries of flowers by webbing with leaves and larvae move from one flower to another, each larva may consume 4-6 flowers before completion of larval development causing serious damage (Taylor, 1967; Raheja, 1976; Mia, 1998;
Sharma, 1998; Mandal et al., 2013). Third to fifth instar larvae are capable of boring into the pods and occasionally into peduncle and stems (Taylor 1967). The young larvae also nibble into the stems of blackgram from leafaxils of branches causing wilt (Goud and Vastrad 1992). Spotted pod borer (Maruca vitrata) is a major constraint for the production of pulses at critical flowering and pod formation stages in the Southern Zone of Andhra Pradesh (Chandrayadu et al., 2008). The yield losses caused by $M$. vitarta have been estimated to be around 30 million dollars annually in India (Saxena et al., 2002). The peak bud infestation $(50.0 \%)$ was noticed during the $2^{\text {nd }}$ week of December i.e., $48^{\text {th }}$ standard week on green gram (Sandhyarani $e t$ $a l ., 2014)$. The grain yield loss due to this pest ranged from 9 to 84 percent on grain legumes (Manjunath and Mallapur 2015). Economic loss of $25-50 \%$ in greengram was reported by Sandhyarani and Eswari (2008).

Managing this pest is very difficult for the farmers due to the typical feeding habit of the larvae and its ability to protect itself from natural enemies and conventional group of insecticides. Repeated use of conventional chemicals results in development of resistance to insecticides. However, farmers mostly rely on chemical insecticides alone due to lack of other control measures against spotted pod borer. Excessive and indiscriminate use of chemical insecticides not only cause economical restrain on farmers but also imposes harmful effects on the environment as well as human beings health. The best way to suppress this hidden pest is by timely observation on the pest incidence, levels of infestation and adoption of integrated management strategies with properly alternating different groups of insecticides so that even with repeated use of insecticides having different mode of action, the pest may not develop resistance against particular group of insecticides besides achieving proper 
management of the pest to keep the damage under check effectively.

Keeping in view of the above, an attempt was made to evaluate and popularise on use of integrated pest management practices and other cultural practices for effectively checking the damage by maruka pod borer in blackgram in the farmers' fields.

\section{Materials and Methods}

The present investigation was carried out in ten locations in farmers' fields of adopted villages of KVK, Ghantasala in Mopidevi mandal of Krishna district for four years from 2014-15 to 2017-18, where farmers cultivate blackgram in large area during rabi season. On farm trials were conducted in selected farmers' fields with an objective to evaluate the performance of 'integrated pest management practices and certain cultural practices so that the same package may be popularized among the farming community for better management of the pest.

\section{T1 - Integrated Pest Management Practices}

Monitor the occurrence of maruka pod borer adult months at flower bud initiation stage of blackgram (35 days onwards)

Spray neem oil $5.0 \mathrm{ml} / \mathrm{lt}$ or NSKE $5 \%$ one week before flowering initiation as and when the adult population is noticed for avoiding egg laying by adults

At flowering initiation spray acephate 1.0 $\mathrm{gm} / \mathrm{lt}$ or thiodicarb $1.0 \mathrm{gm} / \mathrm{lt}$ or chlorpyriphos $2.5 \mathrm{ml} / \mathrm{lt}$ or quinalphos 2.0 $\mathrm{ml} / \mathrm{lt}$ if maruka larvae is present

If webbings are formed by the larvae and feeding inside the web, spray quinalphos $2.0 \mathrm{ml} / \mathrm{lt}$ or chlorpyriphos $2.5 \mathrm{ml} / \mathrm{lt}$ or novuluron $1.0 \mathrm{ml}$ along with dichlorvas $1.0 \mathrm{ml} / \mathrm{lt}$

If infestation is very high, spray emamectin benzoate $0.4 \mathrm{gm} / \mathrm{lt}$ or spinosad $0.3 \mathrm{ml} / \mathrm{lt}$ or chlorantraniliprole $0.3 \mathrm{ml} / \mathrm{lt}$ or flubendiamide $0.2 \mathrm{ml} / \mathrm{lt}$ to reduce the cost of cultivation

Use $200 \mathrm{lt}$ of spray fluid with hand compressor sprayer and with 'Taiwan' sprayer use 70-80 lts adjusting the dose accordingly

Don't spray early in the morning to avoid runoff of spray fluid due to the presence of dew on leaves

\section{T2: Farmers practices (Non IPM)}

a. Use of combination of insecticides (Several rounds of spray of combination of chlorpyriphos, coragen, flubendiamide etc., from early stages of the crop)

Each treatment was imposed in $0.4 \mathrm{Ha}$ with blackgram "LBG 752" variety. Recommended package of practices were followed for raising the crop. Weather conditions during the period of investigation is characterised by temperature range of maximum 26.5 to 32.5 and minimum 10.5 to $20.5{ }^{\circ} \mathrm{C}$ with no rainfall during the crop growth period. The spraying of insecticides was started at the flowering initiation with neem oil $5.0 \mathrm{ml} / \mathrm{lt}$ to avoid egg laying by the adults. With incidence of the pod borer, spraying were done as per schedule. All the sprayings were done by using Taiwan sprayer. Data were recorded from ten randomly selected plants from each field leaving border rows. The observations were recorded on $5^{\text {th }}$ day after spraying for pod damage. The spotted pod borer damage the pods by making holes and webbing the inflorescence whereas, the damage caused by other pod borers results in making holes on the pods without any webbing. The seed yield, cost of cultivation, net benefit and cost benefit ratios were calculated.

\begin{tabular}{lll} 
Per cent pod & \multicolumn{2}{c}{ Damaged pods } \\
damage $=$ & $\begin{array}{l}\text { Total number of } \\
\text { pods observed }\end{array}$ &
\end{tabular}




\section{Results and Discussion}

The results indicate (Table 1) that adoption of IPM module helped in reduction of pest population buildup and thereby the maruka pod borer damage. Farmers prefer high yielding quick growing YMV tolerant blackgram varieties but prone to maruka pod borer for cultivation in rabi season. In 201415 in the IPM plot, where in the initial stages neem oil sprays was done to deter the egg laying by the adult moths, the per cent pod damage was 16 per cent while, and in the farmers practice it was 23 per cent, wherein only chemical insecticides were sprayed indiscriminately. In IPM plot, the seed yield was $18.75 \mathrm{qt} / \mathrm{ha}$ with a 7.14 per cent increase over farmers practices (17.5 q/ha). In 2015-16 in the IPM plot, the per cent pod damage was 11 per cent, while in the farmers practice it was 24 per cent. In the IPM plot, the seed yield was $21.15 \mathrm{qt} / \mathrm{ha}$ with 5.75 percent increase over farmers practices $(20.0 \mathrm{q} / \mathrm{ha})$. In 2016-17 in the IPM plot, the per cent pod damage was 7.5 per cent while, in the farmers practice it was 14.5 per cent. In the IPM plot, the fruit yield was $8.75 \mathrm{qt} / \mathrm{ha}$ with a 16.67 per cent increase over farmers practices (7.5 q/ha). In 2017-18 in the IPM plot, the per cent pod damage was 3.4 per cent while, in the farmers practice it was 6.8 per cent. In the IPM plot, the seed yield was $4.68 \mathrm{qt} / \mathrm{ha}$ with 5.17 per cent increase over farmers practices (4.45 q/ha).

Among the insecticides used by the farmers, the new insecticide flubendiamide belong to benzene dicarboxamide group effective against lepidopteran pests with excellent field efficacy and safe to non target organisams including various beneficial arthropods and natural enemies. Due to these qualities, flubendiamide is suitable for integrated pest management (IPM) programmes (Tohnishi et al., 2010). Flubendiamide 480 SC @ 48 g a.i. ha-1 recorded minimum survival of pod borer population (1.13 and 0.5 larvae/5 plants) in blackgram (Patil et al., 2008 and Kumar and Shivaraju, 2009). Flubendamide 39.35 SC @ $0.2 \mathrm{ml} / \mathrm{l}$ against legume pod borer recorded lowest mean flower or pod damage $6.95 \%$ per plant and recorded highest pod yield 312.50 $\mathrm{kg} / \mathrm{acre}$ in blackgram (Kumar et al., 2017 and Mahalakshmi et al., 2012). Chlorantraniliprole is other new molecule, long lasting and highly effective against lepidopteran pests (Cordova et al., 2006). Lowest mean pod damage of 14.5 per cent and also highest mean larval population (0.67 larvae per plant) was recorded with chlorantraniliprole20 SC @ $20 \mathrm{~g}$ a.i. ha-1 on blackgram (Swathi, 2018).

During the years 2014-15 and 2015-16 the yield levels of blackgram were high compared to the succeeding years. This is due to the fact that the rainfall received (Figure 1) in 2014 and 2015 were considerable compared to normal levels where as in $2016(-21.43 \%)$ and $2017(-53.43 \%)$ the rainfall received was less compared to normal levels.

The cost of cultivation, average gross returns, average net returns and benefit cost ratios calculated in each year were presented in table 2 indicates that adoption of IPM module resulted in reduction of number of sprays of insecticides, thus reducing the cost of cultivation and improving the net income levels. In 2014-15, through adoption of IPM practice, the cost of cultivation was reduced by Rs. 2577.00 with an increase of Rs. 10077.00 in net returns compared to the farmers practice, the benefit cost ratio was 4.65 compared to 3.93 in farmers practice. In 2015-16, the cost of cultivation was reduced by Rs. 2967.00 with increase of Rs. 18967.00 in net returns in IPM plots compared to farmers practice. The benefit cost ratio was 4.76 compared to 3.67 in farmers practice. In 2016-17, the cost of cultivation was reduced by Rs. 5850.00 and an increase of Rs. 8975 in net returns in IPM plots compared to farmers practice. 
Table.1 Details of the blackgram crop yields obtained and maruka pod borer damage

\begin{tabular}{|c|c|c|c|c|c|c|c|}
\hline \multirow[t]{2}{*}{ Year } & \multirow[t]{2}{*}{ Variety } & \multirow{2}{*}{$\begin{array}{l}\text { No. of } \\
\text { farmers }\end{array}$} & \multirow{2}{*}{$\begin{array}{c}\text { Demo. } \\
\text { Yield } \\
\left(\mathbf{q} \mathbf{h a}^{-1}\right)\end{array}$} & \multirow{2}{*}{$\begin{array}{c}\text { Yield of } \\
\text { local } \\
\text { Check } \\
\text { qha }^{-1}\end{array}$} & \multirow{2}{*}{$\begin{array}{l}\text { Increase } \\
\text { in yield \% }\end{array}$} & \multicolumn{2}{|c|}{ Per cent damage } \\
\hline & & & & & & Demo & Local \\
\hline 2014-15 & LBG 752 & 10 & 18.75 & 17.50 & 7.14 & 16 & 23 \\
\hline $2015-16$ & LBG 752 & 10 & 21.15 & 20.00 & 5.75 & 11 & 24 \\
\hline 2016-17 & LBG 752 & 10 & 8.75 & 7.5 & 16.6 & 7.5 & 14.5 \\
\hline 2017-18 & LBG 752 & 10 & 4.68 & 4.45 & 5.17 & 3.4 & 6.8 \\
\hline
\end{tabular}

Table.2 Details of cost of cultivation, average gross and net income levels

\begin{tabular}{|c|c|c|c|c|c|c|c|c|}
\hline \multirow[t]{2}{*}{ Year } & \multicolumn{2}{|c|}{$\begin{array}{c}\text { Average Cost of } \\
\text { cultivation (Rs. ha } \\
\text { culion }\end{array}$} & \multicolumn{2}{|c|}{$\begin{array}{l}\text { Average Gross } \\
\left.\text { Return (Rs. ha' }{ }^{-1}\right)\end{array}$} & \multicolumn{2}{|c|}{$\begin{array}{l}\text { Average Net } \\
\text { Return (Profit) } \\
\quad\left(\text { Rs. ha }{ }^{-1}\right)\end{array}$} & \multicolumn{2}{|c|}{ BC ratio } \\
\hline & Demo & $\begin{array}{l}\text { Local } \\
\text { Check }\end{array}$ & Demo & $\begin{array}{l}\text { Local } \\
\text { Check }\end{array}$ & Demo & $\begin{array}{l}\text { Local } \\
\text { Check }\end{array}$ & Demo & $\begin{array}{l}\text { Local } \\
\text { Check }\end{array}$ \\
\hline 2014-15 & 24173 & 26750 & 112500 & 105000 & 88327 & 78250 & 4.65 & 3.92 \\
\hline 2015-16 & 25073 & 25000 & 117000 & 101000 & 90200 & 88340 & 4.66 & 4.04 \\
\hline 2016-17 & 32600 & 38450 & 48125 & 45000 & 15525 & 6550 & 1.48 & 1.17 \\
\hline 2017-18 & 29698 & 30700 & 53820 & 51175 & 24122 & 20475 & 1.81 & 1.67 \\
\hline
\end{tabular}

Figure.1 Graph showing the rainfall received in different years from 2014-17

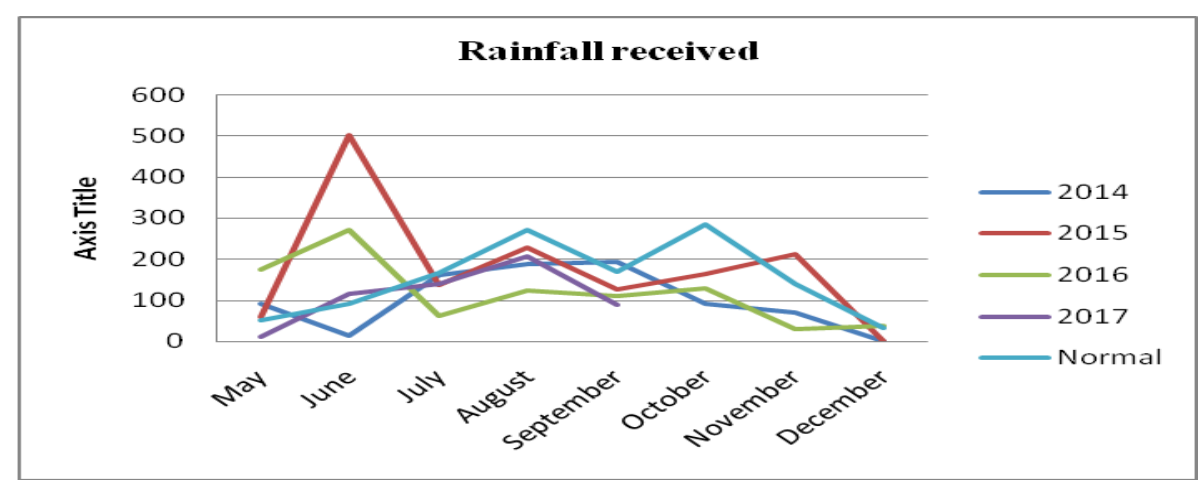

The benefit cost ration was 1.48 compared to 1.17 in farmers practice. In 2017-18 also, the cost of cultivation was reduced by Rs. 1002.00 with an increase of Rs. 3647.00 in net returns in IPM plots compared to farmers practice. The benefit cost ration was 1.81 compared to 1.67 in farmers practice. The data indicates that by adoption of IPM practices with emphasis on decision making for insecticides application based on pest intensity can be used as a tool for avoiding unnecessary sprays leading to reduction in pest management cost and improving the net returns.

\section{Acknowledgment}

The authors are grateful to the Programme Coordinator, Krishi Vigyan Kendra, Ghantasala for providing facilities and 
extending support to carry out the investigation.

\section{References}

Chandrayadu E, Srinivasan S, Venugopala Rao N. 2008 Evaluation of certain new insecticides against spotted pod borer, M. vitrata (Geyer) on cowpea (Vigna ungiculata (L) Walp). Current Biotica. 2(2):240-243.

Cordova D, Benner EA, Sacher MD, Rauh JJ, Sopa JS, Lahm GP 2006. Anthranilic damides: a new class of insecticides with a novel mode of action, ryanodine receptor activation. Pesticide Biochemistry and Physiology. 84(3):196-214.

Dhuri AV, Singh KM. 1983 Pest complex and succession of insect pests in blackgram. Indian Journal of Entomology. 45:396401.

Goud KB, Vastrad AS. 1992 Record of Maruca testulalis (Geyer) infesting stem of blackgram in Dharwad, Karnataka. Karnataka Journal of Agricultural Sciences. 5: 270-271.

Justin GLC, Anandhi P, Jawahar D. 2015 Management of major insect pests of blackgram under dry land conditions. Journal of Entomology and Zoology studies. 3(1):115-121.

Kumar A, Sachan Sk, Kumar S, Kumar P. 2017 Efficacy of some novel insecticides against whitefly (Bemisia tabaci Gennadius) in brinjal. Journal of Entomology and Zoology Studies. 5(3):424-427.

Kumar CT A, Shivaraju C. 2009 Evaluation of newer insecticide molecules against pod borers of blackgram. Karnataka Journal of Agricultural Sciences. 2009; 22(3): 521-523.

Lal SS, Sachan JN. 1987 Recent advances in pest management in pulses. Indian Farming. 37: 29-32.
Lal, S.S. 1985. A review of insect pests of mungbean and their control in India. Tropical Pest Management. 31(2): 105114.

Mahalakshmi MS, Ramarao CV, Koteswararao Y. 2012 Efficacy of certain newer insecticides against legume pod borer, Maruca vitrata in urdbean. Indian Journal of Plant Protection. 40(2):115-117.

Mandal D, Bhowmik R, Chatterjee M. 2013 Field efficacy and economics of some insecticides against spotted pod borer Maruca testulalis (Geyer) of blackgram Journal of Crop and Weed. 9:177-180.

Manjunath GN, Mallapur CP. 2015 Studies on population dynamics of spotted pod borer, Maruca testulalis Gey. In blackgram. Karnataka Journal of Agricultural Sciences. 28(3):418-419.

Mia MD. 1998 Current status of insect research of pulse crops and future research needs. In Proceedings of the workshop on disease resistance breeding in pulses Thana cereal technology transfer and identification project, Dhaka, 1998, 87-93.

Mohanraj A, Bharathi K, Rajavel DS. 2012 Evaluation of chlorantraniliprole $20 \%$ SC against pests of blackgram. Pestology 36(4): 39-43.

Nayar KK, Ananthakrishnan TN, Devid BV. 1976 General and applied entomology, Tata McGraw Hill Publication Cooperative Limited, New Delhi, 589.

Pandey SN, Singh R, Sharma VK, Kanwat PM. 1991 Losses due to insect pests in some kharif pulses. Indian Journal of Entomology. 1991; 53(4): 629-631.

Patil SK, Deshmukh GP, Patil JV. 2008. Efficacy of flubendiamide 480 SC against pod borers in blackgram. Pestology. 32(9): 20-22.

Rabindra R J, Ballali C R and Ramanujan B. 2004. Biological options for insect pests and nematode management in pulses. 
(in) Pulses in New Perspective, Kalyani Publishers, New Delhi, India. pp. 487.

Raheja AK. 1976 Assessment of losses caused by insect pests to cowpeas in northern Nigeria. PAANS. 22:229-233.

Reddy A. 2009. Pulses Production technology: Status and way forward. Econ. Pol.Weekly 34(52) 73-80.

Sandhyarani C, Rao GR, Chalam MSV, Kumar PA, Rao VS. 2014 Seasonal incidence Of spotted pod borer, Maruca vitrata (Geyer) (Pyralidae; Lepidoptera) on greengram in Rabi. The Andhra Agricultural Journal. 61(4):871- 874.

Sandhyarani, C. and Eswari, K.B. 2008. Evaluation of some newer insecticides against

Saxena HP. 1983 Losses in blackgram due to insect pests. Indian Journal of Entomology. 1983; 2:294-297.

Saxena KB, Chandrasena GDSN, Hettirachchi K, Iqbal YB, Fonseka HHD, Jayasekara SJBA 2002 Evaluation of pigeonpea accessions and selected lines for reaction of $M$. vitrata (Geyer). Crop Science. 42:615-618.

Sharma HC. 1998 Bionomics, host plant resistance and management of the legume pod borer, Maruca vitrata A review. Crop Protection. 1998; 17:373386.

Sharma KK, Yadav HS, Chandra A. 2000 A note on seasonal activity of pod borer complex on dolichos bean. JNKVV Research Journal. 33(1):74-77.

Shivaraju C, Kumar CTA, Sudhir KS, Thippaiah M. 2011 Seasonal incidence of pod borer complex on blackgram, Vigna mungo (L). Journal of Entomological Research. 35(1):39-42.

Singh SR, Allen DR. 1980 Pests, diseases, resistance and protection in cowpea. Advances in Legume Science, 1980, 419-433.

Swathi K. Study on Seasonal Incidence and Insecticidal Management of Major Insect Pests of Rice Fallow Black gram (Vigna mungo L.) in North Coastal Andhra Pradesh M.Sc. (Ag.) Thesis submitted to Acharya N. G. Ranga Agricultural University, Lam Guntur, Andhra Pradesh 2018.

Taylor TA. 1967 The bionomics of Maruca testulalis Gey. a major pest of cowpea in Nigeria. Journal of West Africa Science Association. 12:111-129.

Tohnishi M, Nishimatsu T, Motoba K, Hirooka T, Seo A. Development of a novel insecticide, flubendiamide. Journal of Pesticide Science. 2010; 35(4):490-491.

Vyavasaya Panchagam, 2018 Acharya N. G. Ranga Agricultural University. Guntur pp. 78.

\section{How to cite this article:}

Sudha Jacob, P. and Revathi. 2019. Maruka Pod Borer [Maruca vitrata (Geyer)] Management in Blackgram (Vigna mungo L.) in Krishna District of Andhra Pradesh, India. Int.J.Curr.Microbiol.App.Sci. 8(07): 2316-2322. doi: https://doi.org/10.20546/ijcmas.2019.807.283 